\title{
DIAGNOSIS OF THE WORLD'S ELASTIC CURRENCY PROBLEMS
}

\author{
By Andrew J. Frame, \\ President Waukesha National Bank, Waukesha, Wisconsin.
}

Professor Sumner, in his "History of American Currency," said, in summing up the doctrines of the celebrated bullion report which was submitted to the House of Commons in I810, "Its doctrines are the alphabet of modern finance. They are no longer disputable." Another section reads, "In the presence of a panic the duty of the bank is to discount freely to all solvent parties."

I take it, a smile will pass over the features of my banker friends the moment their ne'er-to-be-forgotten practical experiences of 1893 and 1907 loom up as a nightmare before them again. How can a bank discount freely to all solvent parties when its panic-stricken depositors want all the cash the bank holds, and very quickly too?

What is the meaning of the word panic? The Standard Dictionary says: "The prevalence of unreasoning and overpowering alarm in financial and commercial circles, or in both, leading to sudden and stringent restrictions of credit and great shrinkage in values, and precipitating mercantile and banking failures; often the precursor of a financial panic."

Panics undoubtedly cannot be wholly prevented except in theory by such dreamers as Bellamy, who support the impossible idea that human nature can be changed, speculation cease and optimism be eradicated from Anglo-Saxonism.

Notwithstanding this, I am a firm believer in ameliorating panic conditions, both as to their frequency and as to their severity. But how? My answer is:

(I) By studying history and profiting by the experiences of the past.

(2) By passing conservative and sound banking laws, and then enforcing them.

(3) By giving as much elasticity to the circulating medium as can be safely attained, but never to reach an amount which engenders 
doubt in the public mind as to its redemption in the world's standard of value.

As to the problem of conservative and sound banking laws and enforcement, the national banking system is the safest and best this country has known. It is a well-known fact that some states have good laws, some lax laws, and others none at all. It is also a matter of gratification to know that many states are working along the line of betterment. With thirteen thousand million dollars due to not less than sixteen million depositors in the banks and trust companies of the United States, in order that conditions leading to panics and their paralyzing effects may be minimized, is it not the clear duty of our statesmen to perfect, as far as possible, conservative laws on sound lines?

These laws should demand ample capital paid in, limitations on loans to any person or firm, and reasonable reserves according to whether deposits are payable on demand or on time. As space forbids further pursuit of this phase of the subject, I will confine myself to the knotty "elasticity problem."

\section{The Elasticity Problem}

The history of the progress of nations during the earlier centuries shows an evolution from the use of bullocks as a medium of exchange, as recorded in the Bible, to the later period of barter by the use of beads, nails, skins, shells, etc. In later centuries, in addition to the limited quantities of coin, the banks have indulged more or less in the issue of so-called asset or credit currency, dubbed "coined credit," by Professor Sumner, as well as currency secured by various kinds of collateral. All makeshifts have in the most advanced and progressive nations given way to the world's standard of value-gold, until to-day those progressive nations which issue currency do so largely through one great central bank. The immense coin reserves of these great banks practically make their currency issues a gold certificate payable on demand. They are practically banks of issue and not of deposit, as will be seen by the table which follows. These banks issue more or less currency in excess of coin held, but some are based on government securities, as in England; all their loans are amply secured and of a quick liquid character. In view of these facts, these great banks, with immense capital, coin reserves and small liabilities, 
are in a position to expand currency issues to move crops without distrust, and under panic conditions "to discount freely to all solvent parties," also to furnish extra cash to banks with which to meet the insane demands of frightened depositors, thus preventing general paralysis of trade and industry in all branches, which is inevitable if forced liquidation takes place which is so destructive to labor and capital alike.

I am firmly convinced that if the United States had lately had a large central bank of the banks, commensurate with our greatness, notwithstanding the colossal pyramid of credit which we have been building, we might have been let down by easy stages, instead of falling off from the top of the building, producing a jar that seems to have shaken the whole commercial world. I an also convinced that if the last Congress had authorized asset or credit currency on the American Bankers' Association plan, when the I907 spasm struck us, our troubles would simply have doubled.

Let us briefly diagnose the reasons therefor by a comparison of European conditions with those of the United States as they exist to-day.

Capital, specie, circulation, etc., of the great European single banks of issue on or about June 30, Igo6.

TABLE No. I.

In Millions.

\begin{tabular}{|c|c|c|c|c|}
\hline Capital. & $\begin{array}{l}\text { Circula- } \\
\text { tion. }\end{array}$ & Deposits. & $\begin{array}{c}\text { Total } \\
\text { specie. }\end{array}$ & Loans. \\
\hline Imperial Bank of Germany ......\$28.9 & $\$ 412.0$ & $\$ 149.9$ & $\$ 2$ II.I & 7 \\
\hline Bank of Austria-Hungary .... & 376.5 & 31.6 & 299.2 & \\
\hline National Bank of Belgium . ..... 9.6 & I36.5 & I6.3 & 24. I & 124.8 \\
\hline National Bank of Bulgaria ....... 1.8 & 8.6 & 17.0 & 7.6 & I I.9 \\
\hline National Bank of Denmark ..... 6.8 & 34.9 & .8 & 27.2 & I3.7 \\
\hline Bank of Spain $\ldots \ldots \ldots \ldots \ldots \ldots \ldots 28.9$ & 305.7 & 134.2 & 200.2 & I 54.4 \\
\hline Bank of Finland $\ldots \ldots \ldots \ldots \ldots$ r.9 & 18.2 & 4.2 & 5.2 & II. 7 \\
\hline Bank of France $\ldots \ldots \ldots \ldots \ldots \ldots 35.2$ & 908.8 & I89.I & 803.4 & $255 \cdot 3$ \\
\hline National Bank of Greece . . . . . . . 3.9 & 23.I & 23.4 & .4 & 2 ז.6 \\
\hline Bank of Italy . . . . . . . . . . 28.9 & 213.3 & 90.6 & I52.7 & 9 r.6 \\
\hline Bank of Naples ....... & 66.6 & I6. I & 32.8 & 34.5 \\
\hline Bank of Sicily .. & $\mathbf{1} 4.8$ & Io.6 & 9.1 & 10.9 \\
\hline Bank of Norway & $2 \mathrm{I} .4$ & I.9 & 8.0 & 12.0 \\
\hline Bank of Netherlands .......... 8.o & I 13.0 & 2.5 & 57.I & 59.8 \\
\hline ank of Portugal $\ldots \ldots \ldots \ldots \ldots \ldots$ & 74.5 & 29.3 & I3.7 & 26.5 \\
\hline
\end{tabular}




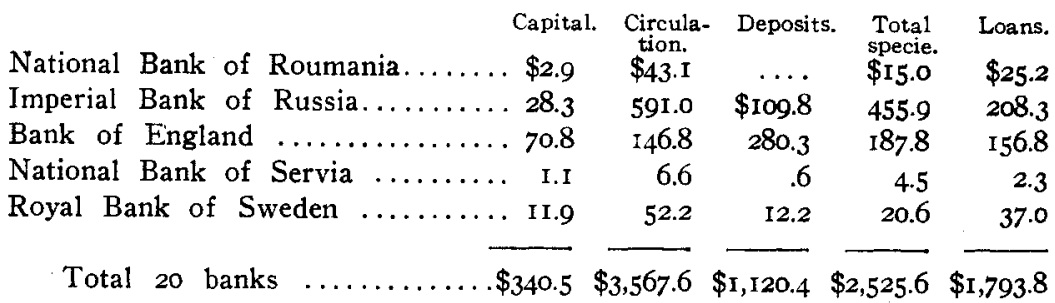

The foregoing, practically banks of issue and not of deposit, show demand liabilities versus coin reserves, as compdred to the national banks of issue in the United States, as follows:

In Millions.

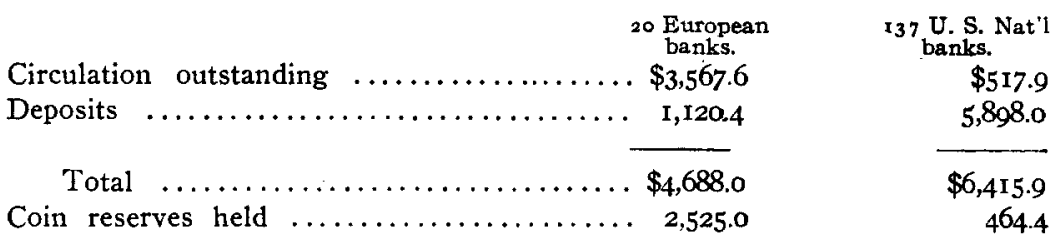

Mark the fact that the great issuing banks of Europe hold 54 per cent of demand liabilities in coin, as against only 7 per cent in the United States.

Mark that, as records show, the total currency issues by all the other great European banks of deposit on June 30, I906, approximated but 150 millions of dollars, and when the charters of the four German banks and those of Great Britain and Switzerland expire, the right to issue currency by all of them being doomed, there will be few left in Europe to issue currency except these twenty great centralized banks and the new bank of Switzerland.

Do not the foregoing facts conclusively show that the progressive European nations each have one great issuing bank, which might be termed the governor to the engine, expanding and contracting automatically without distrust, because they have immense coin reserves and quick assets, and that the issue of credit or any other kind of currency by small, independent banks has practically been totally abolished all over Europe?

This result in Europe was evidently brought about through the dear school of experience. Let us touch upon a few most salient instances abroad. 


\section{France}

John Law, nearly 200 years ago, after being turned down by the keen Scotchmen, captured the French people with his plausible populistic inflation scheme, and history tells us that France did not recover from its terrible effects for fifty years. The statesmen of France, not content with the John Law experiment, in consequence of business depression in 1789 , instead of manfully waiting for a natural return of better days, in response to the popular clamor for "more money," sought to take a short cut to prosperity by issuing heroic quack doses of fiat money for several years in succession. Just as soon as the effects of the first issues began to show symptoms of a reaction upon business, another larger dose was administered to the already staggering patient.

The statesmen of France, in most eloquent perorations-which might be likened to some in these latter days-swayed the multitude so far that the intoxication for assignats grew until nearly 40,000 millions of francs were outstanding in 1797 , a sum aggregating nearly three times our whole circulating medium to-day. With one fell swoop the French nation repudiated the whole issue.

The Bank of France was organized in 1800 with about $\$ 6,000$,ooo capital, which at various times was increased, until to-day it is about $\$ 35,000,000$. It has power to issue notes with the following prerequisites, as dictated by Napoleon: "The notes shall be covered either by coin held by the bank or by notes secured by collateral or by notes signed by three responsible persons." A strong effort was made at that time to give the right of issue to the banks generally in France, but Napoleon answered in substance,-It is easier to watch one bank of issue than it is to watch great numbers. His logic exactly condemns the American Bankers' Association plan to-day. What has been the result in France? The foregoing table shows:

Millions.

Circulation $\ldots \ldots \ldots \ldots \ldots \ldots \ldots \ldots \ldots \ldots \ldots \ldots \ldots \ldots 9 . \ldots \ldots . . . \ldots$

Coin on hand is $881 / 2$ per cent of circulation .......... 803.4

If we add the deposits of $\ldots \ldots \ldots \ldots \ldots \ldots \ldots \ldots \ldots$ I 89.1

to circulation outstanding, the bank still would show about 73 per cent of coin against all liabilities, as against 7 per cent for the national banks of the United States. We must not forget also that the $\$ 255.3$ millions of loans are of a much more liquid character 
than are those of the national banks generally throughout the United States.

The Bank of France has been managed with such consummate skill that even during the Franco-German war the depreciation of its notes was only 4 per cent. It also during the past century rendered invaluable aid by loaning coin to the Bank of England during several crises in Britain. The bank, with its vast coin reserves and quick assets has been enabled to loan freely to all solvent parties under panic conditions, thus undoubtedly preventing panics at times, and it has steadied the financial convulsions in France for a century. The Bank of France has had the sole right of issue in France since 1848 . Its uncovered currency averages about $\mathrm{I} 20$ million dollars, which indicates no currency inflation in France as against 900 millions in the United States to-day.

\section{England}

The Bank of England was chartered in I694. Although it was of great value to mercantile interests in several financial crises, yet as the bank had limitless authority to issue notes, and there was no rule as to coin reserves from 1694 to 1844 , at which date Peel's Act "gave the Old Lady of Threadneedle Street the straight jacket she has worn ever since," Bagehot, in his classic work entitled "Lombard Street," says, "This unbridled authority was in more than one instance used with the extremest unwisdom, so that devastating panics followed hard upon the heels of the reckless speculation which too great facilities for borrowing had engendered." Such dearly-bought experiences ought to warn us against easy methods of inflation. English statesmen battled for a quarter of a century with the subject of whether gold was at a premium or a redundant quantity of Bank of England notes at a discount. The question was finally settled in 1816 by the adoption of the profound "Bullion Report of I8ro." The integrity of her gold standard of payments has since been maintained with a fidelity that commands the admiration and confidence of the whole world, to the extent that London is the world's clearing house, and practically all the nations of the earth pay tribute to Britain. The paramount question to us is, how soon will New York City displace London as the world's clearing house, if we keep on injecting more non-standard currency into our already redundant currency issues? 
Under Peel's Act, the banks of Great Britain in 1844 were restricted on issues of bank notes to the amount then outstanding by the banks then existing. Seventy per cent of the right of issue of those banks which have closed since 1844 , has reverted to the Bank of England, thus reducing the total uncovered issues allowed to banks in general, all of which are subject to the unlimited liability act as to note issues, to the small sum of approximately $£ 8,000,000$, and has increased the issues of the Bank of England since 1844 from $\ell_{14}, 000,000$ to about $\ell_{1} 8$, I75,000 based on securities. All other issues of the bank are covered with gold coin or bullion, thus making the notes practically gold certificates and giving the Bank of England the sole right of issue in Britain. The total uncovered issues in Britain average about $\$ 120,000,000$, of which $\$ 90,000,000$ are Bank of England notes based on government securities. Scotch banks, so much harped about, can issue but $£ 2,676,350$ uncovered notes. As extraordinary troubles require extraordinary remedies, in order to ameliorate some of the calamitous panic conditions which have overtaken Britain, history says, the Bank of England in 1847,1857 and 1866 , after the panics had paralyzed her progress, on the assurance of the government officials that no prosecution would follow, suspended the bank act as to issuing notes only on the deposit of a like amount of either coin or bullion, and it issued notes to the banking department on deposit by it with the issue department of ample securities. This was an unlawful act, giving elasticity to the currency, but it placed the banking department in an easy condition to "discount freely to all solvent parties." Again, in 1838 , the bank borrowed $£ 2,500$,ooo from the Bank of France during panic conditions, and in 1890 , during the Baring troubles, she borrowed $\mathfrak{f}_{3}, 000,000$; besides $\pm 2,000,000$ from outside sources, and the panics were stayed. The Barings failed for $\$ 105,000,000$ and yet their indebtedness was liquidated by the Bank of England with the aid of other local banks without general suspension of cash payments as experienced in the last months of 1907 in the United States. The apparent necessity for these extraordinary acts was that the country had reached a commercial crisis where good securities could not be sold for cash. Suspension and consequent ruin were staring sound commercial houses and banks in the face.

In each case the action of the bank afforded instant relief and 
doubtless saved hundreds of millions of dollars to tottering houses unable to meet payments except for uch relief. As soon as the pressure was over the illegal issues were retired.

These unlawful 'acts were parallel to our clearing-house certificates, except that clearing-house certificates have but limited use, whereas the Bank of England notes satisfy the insane demands of frightened depositors and give sufficient elasticity to meet necessary demands for loans to solvent parties so that the wheels of commerce be not stilled. Should the Bank of England be legally empowered to relieve extraordinary pressure on the same lines as in $1847^{\circ}, 1857$ and 1866 before paralysis takes place, the benefits undoubtedly would be incalculable. Nearly all political economists criticize this feature, which seems to be the only material defect, without which the Bank of England would be ideal in practically all respects.

\section{Germany}

With the exception of only four banks, which are allowed to issue say eighteen millions of dollars of uncovered notes-and these privileges are doomed-the Imperial Bank of Germany monopolizes that right. The bank is allowed to issue now about $\$$ I 2,500,000 uncovered circulation under certain restrictions. Any excess over that sum must pay 5 per cent interest per annum to the government. This excess issue is the only true nethod by which to obtain relief under panic conditions, as the interest rate will certainly retire the redundant currency as soon as the pressure for funds is over, thus preventing inflation.

It is a noteworthy fact that the Imperial Bank of Germany has raised its discount rate to 7 per cent but once in thirty years, except during our panic of 1907 , when its rate was raised to $7 \mathrm{r} / 2$ per cent. It is also a noteworthy fact that during that thirty-year period the bank issued such 5 per cent taxed currency I2I times as a relief measure under pressure. The Austro-Hungarian bank did likewise under similar conditions fifty-five times in the past eighteen years. In the face of the fact that interest rates are lower there than here, such 5 per cent taxed currency automatically expands under pressure and contracts as soon as the pressure is over, thus preventing inflation. This fact defies theory and upsets the absurd claim that a high taxed currency imposes 
such a tax on commerce that banks will not use it. Germany's uncovered currency averages say $\$ 150,000,000$, which is a wide contrast to our $\$ 900,000,000$ and over to-day.

But enough. These details and the foregoing table are conclusive evidence that elasticity in Europe, by an evolutionary process, has been achieved without producing distrust or inflation.

\section{Issuing Currency is not a Necessary Banking Function}

Further, it does not seem to be a necessary function of banks generally in Europe to issue currency at all. As state and other banks in the United States issue no currency, I assert the special privilege ought to be abolished as to the other third, as soon as the banks owning the abnormally low rate 2 per cent interest bonds can obtain payment for them. Banks holding them run great risk of material depreciation should the government for any cause be compelled to issue large sums additional. Let the United States sell its bonds strictly on their merits, as every other nation does. This result ought to be brought about by a slow evolutionary process, and under natural economic laws the channels of circulation would automatically fill the vacuum created with the world's standard-gold. Adam Smith gives an illustration in point in his "Wealth of Nations"-."Money, like wine, must always be scarce with those who have neither the wherewithal to buy or the credit to borrow it. Those who have either will seldom be in want of either the money or the wine which they have occasion for, and a country that has wherewithal to buy gold or silver, will never be in want of those metals." I am strongly impressed that the United States has the wherewithal to buy all the gold and silver we need for a basis of our circulating medium. If some of the poor sections of our country are short on circulation, is it not because they are also short on collateral or wherewithal to buy it?

\section{The Lesson from American History}

Let us turn to the United States without specific reference to the disastrous results of continental currency in the eighteenth century, which might be excusable, as the birth of the nation was at stake. The "History of Banking in all Nations" says, in referring to all banks of issue from I739 to I84I, "The esti- 
mated losses on their circulation were I8.I millions of dollars." Again, on page 337-under "Free and Safety Fund Banking in New York State," "the notes of twenty-five of them were rejected, and all the safety fund notes were at a discount." Again, "In December (I840), it was reported that few brokers would buy the notes of any free banking association," "and the notes of many of the safety fund banks of the interior are regarded with great distrust." John J. Knox, in his history says that from I789 to I864 "the probable losses to noteholders were about 5 per cent per annum." Further, the circulating notes of the state banks were subject to violent expansion in times of confidence and sudden contraction when distrust occurred. The runs on the banks were not made by the depositors (for they were few), but by the noteholders.

The pages of these authorities, as well as many others, are strewn with proofs of the sickening details of losses to noteholders, caused by bank issues, some based on credit and others based on various collaterals, clear through the eighteenth, and even past the middle of the nineteenth century. Because much of the currency issued during the latter period was secured by collaterals instead of being a pure credit currency, the nineteenth century experiences lessened materially the comparative losses to noteholders everywhere, but still they were calamitous in results up to the end of the "wild cat" days in the United States. Two generations have passed since then wherein no man has lost a moment's sleep over his absolutely secured national bank notes. We ought not to need, like children, to be told to keep away from the fire. We ought to profit by the experience of the past before trouble overtakes us again.

That word "elasticity" is a sweet morsel to play upon the credulity of an innocent public. It has worried the political economists of all ages. Its ghost still stalks forth in this enlightened day.

\section{Panics and the Monetary Standard}

All property was measured in depreciated currency in 1865 , when gold was 100 per cent premium and over. Then the premium began to decline year by year, and all property in proportion, until 1873, by which time values had shrunk to about one-half of the prices of 1865 . This process undermined all prosperity and was 
the underlying cause of the panic of 1873 . After specie payments were resumed in 1879 confidence and prosperity revived with a bound, and they have been forging onward and upward ever since at a pace which has astonished the world. A campaign of education has been constantly and successfully waged toward the establishment of the world's standard-gold-upon an unequivocal foundation. Distrust of our standard halted us from 1893 to 1896 , when the repudiators were repudiated, and since that date the Gold Standard Act of March I4, I900, has been written into our statutes, and thus the battle of the standards has been practically won. There are two links missing to complete the chain. They are the elimination of some of our redundant soft money issues, and the adoption of some sound relief measure when panic threatens.

Since 1896 , when confidence was restored as to the integrity of our standard of value, the wave of prosperity has been almost continuously rising higher and higher. Under the impetus of rapid fortunes acquired by some Napoleons of finance since I 896, who foresaw that a swelling tide of prosperity was at hand, the get-richquick fever intoxicated the many. Nature has been generous in her bounties to us, thus aiding in the development of the rising tide. Another force has been the immense increase in the world's production of gold for the past few years, which doubtless has stimulated the activities and credit expansion of the whole commercial world.

During this period our credit system has grown to collossal proportions. As shown by official statistics, our banking power has increased from 5,150 millions of dollars in 1890 to nearly 18,000 millions of dollars on January I, I908, which nearly equals the banking power of the rest of the world. The individual deposits have more than trebled in that period, which largely represents actual not fictitious capital. The gigantic general statistics of our wonderful progress and present condition are too numerous and too well known to repeat.

During the past ten years our circulating medium has doubled in quantity (from 1,500 to 3,000 millions of dollars), until, as a basis for this mighty superstructure of credit, we hold the following amounts of the world's standard of value, that stands through storm as well as sunshine: 
TABLE No. 2.

In gold coin, say $\ldots \ldots \ldots \ldots \ldots \ldots \ldots \ldots \ldots \ldots \$ 1,600,000,000$

In addition we have:

In silver (say one-half fiat) about .......... $700,000,000$

Legal tender notes ................... $346,000,000$

National bank notes, about $\ldots \ldots \ldots \ldots \ldots \ldots \ldots .690,000,000$

$\$ 1,736,000,000$

By way of comparison with the most progressive nations, permit the following approximate:

TABLE No. 3 .

In Millions.

\begin{tabular}{|c|c|c|c|c|}
\hline & Gold. & Silver. & $\begin{array}{l}\text { Uncovered } \\
\text { currency. }\end{array}$ & $\begin{array}{l}\text { Per capita } \\
\text { circulation. }\end{array}$ \\
\hline United States holds & $\$ 1,600$ & $\$ 700$ & $\$ 900$ & $\$ 35.50$ \\
\hline Great Britain holds ........ & 559 & II7 & I 16 & 18.08 \\
\hline France holds & 1,032 & 400 & $\mathrm{I} 2 \mathrm{O}$ & 39.94 \\
\hline Germany holds & 917 & 200 & 180 & 22.18 \\
\hline
\end{tabular}

This table shows the United States has nearly as much silver as Great Britain, France and Germany combined, and more than twice as much uncovered currency as all combined. It also shows a per capita circulation almost equal to that of France, where cash instead of checks is used much more extensively than here. This per capita circulation is also so far in excess of either Great Britain or Germany that the redundancy of our currency must be apparent to all.

\section{The Barometric Signal}

In view of all these facts, even before the explosion caused by the wild speculation and pyramid banking of the Heinze, Morse, Thomas, etc., outfit; in view of the fact that a high interest rate the world over is the sure barometric signal that the great pyramid of credit has grown beyond the limits of prudence; in view of the handwriting upon the wall as recorded by all the standard authorities on political economy that optimism had outrun conservatism, and that the primary cause of our troubles is over-speculation, I will only quote in proof from one standard authority. Professor Sumner, in his "History of American Currency." tersely sums up the case as follows: "Over-speculation is speculation which outstrips 
the capital of the country;" further, "When we lose our heads in the intoxication of our own achievements, look on currency anticipations, which are only fictitious capital, as if they were real, use them as already earned, build other expansions upon them, then we bring a convulsion and a downfall; some time or other a liquidation must come: . . . then credit breaks down and there must be a settlement, a liquidation, a dividend, a new start." I say, in 5 iew of all these facts, I cannot understand why the powers that be in the great American Bankers' Association, who ought to be the leaders in conservatism, should undertake to bring about a sentiment to commit this country to eighteenth century fiatism again, by the issue-on top of our vast volume of soft money issues-of over two hundred million dollars of asset or credit currency, as a starter only, according to one of the most aggressive advocates, with only 5 per cent secured and 95 per cent fiat, under the plea of providing an elastic currency to move the crops, notwithstanding crops could not move faster, as transportation facilities have been taxed to their utmost for years. Who wants to move the earth to-day and lie idle to-morrow?

\section{The American Bankers' Association Plan}

The American Bankers' Association plan, boiled down and put in cold type, can fairly be diagnosed in this way:

(I) National banks (none others need apply), big and little, in city or country, can indite a letter as follows:

\section{Comptroller of the Currency,}

Washington, D. C.

Please send to this bank the $\$ 25,000, \$ 50,000$ or $\$ 100,000$ of asset or credit currency to which it may be entitled; keep 5 per cent of it on deposit as collateral security; express the other 95 per cent to us, and we will return the same to you at our pleasure, plus $2 \frac{1}{2} 2$ per cent per annum.

Very respectfully,

Cashier.

(2) The Comptroller of the Currency shall designate numerous redemption cities conveniently located in various parts of the 
country. Through the agency of the banks in such cities adequate facilities shall be provided for active daily redemption of credit notes. (The advocates of this redemption plan now admit it impractical, so no answer to it is necessary.)

(3) A bank (credit) note is essentially the same in principle as a deposit payable on demand. This is an amazing conclusion. Political economists say, "Coined credit" in the shape of I O U's. issued by banks is fictitious capital. A deposit generally represents actual capital, so no further argument on that point seems necessary.

In reply to the foregoing I issued the following five challenges in a debate before the State Bankers' Association of Minnesota in July, I907, in response to John L. Hamilton, ex-President of the American Bankers Association, who advocated the American Bankers' Association plan, to wit:

( I) I respectfully challenge any member of the currency committee or any advocate of asset currency to point to a single progressive country on the earth where small, independent country banks are allowed to issue currency backed by only 5 per cent collateral, the remaining 95 per cent of such currency being purely fiat.

(2) I challenge any man to prove that easy methods of issuing currency have not been discarded in all progressive nations.

(3) I challenge any man to disprove the fact that, with but few exceptions, where charters have not expired, in all progressive nations, only great centralized banks, with very large reserves and rigid restrictions as to loans, are allowed to issue currency at all, and the right to issue is limited under rigid restrictions referred to later.

(4) I challenge any man to prove that the method of redemption proposed-which the asset currency advocates claim as the crucial test of success or failure-has any parallel on earth, or affords any practical assurance that it will work under our banking system.

(5) I challenge any man to prove that "a bank note is essentially the same in principle as a deposit payable on demand," or that "it resembles in character . . . a current deposit liability of the bank." 
After the debate what was the verdict of the Minnesota jury? The answer is found in the condemnation of the American Bankers' Association plan, as will be seen by the passage of the following resolution unanimously:

WhEREAS, The prosperity of our country is due in a large measure to the absolute confidence of our people in our present currency, be it

Resolved, That while we are strongly in favor of some well-secured method to relieve monetary stringencies that will not produce inflation, yet we are unalterably opposed to any plan or change in our currency that does not afford absolute security; hence we do not look with favor upon the plan proposed by the American Bankers' Association committee.

Later, after listening to John Perrin, President of the American National Bank of Indianapolis and member of the association currency committee, in favor of its plan, the State Bankers' Association of Wisconsin passed the same resolutions with only two dissenting voices. Still later,-after the meeting of the American Bankers' Association at Atlantic City, when, with practically an empty house and under discreditable conditions, the plan was apparently endorsed,- - the State Bankers' Association of Indiana, after a full debate on the same subject, where O. A. Watts, President of the First National Bank, of Nashville, Tenn., took the affirmative, and I had the honor of the negative side, notwithstanding a strong effort to table the resolutions by able representatives of the American Bankers' Association, the Hoosiers turned down the plan by indorsing in full the same resolutions.

These facts, representing the judgment of bankers when a fair hearing could be had, indicate clearly that the banks of the country generally are against fiat money. The committee of the American Bankers' Association evidently doubted the soundness of their own proposition, as is evidenced by the self-indictment contained in the following quotation taken from the Atlantic City currency committee reported to the convention:

In all our recommendations principle has, to a greater or less degree, been subordinated to practicability. We have recommended, not what we believe, in the light of experience and existing conditions, to be best for the interests subserved, but what, in the light of existing political conditions, we believe to be attainable, not what was best, but what we might reasonably hope to obtain. 


\section{President Roosevelt's Opinion}

President Roosevelt clearly grasps the essential weakness of the plan, as will be seen in the following quotations from his last message to Congress, when he refers to the absorbing currency question:

We need greater elasticity in our currency; provided, of course, that we recognize the even greater need of a safe and secured currency, . . . Provision should be made for an emergency currency. The emergency issue should, of course, be made with an effective guaranty, and upon conditions carefully prescribed by the government. Such emergency issue must be based on adequate securities approved by the government and must be issued under a heavy tax. This would permit currency being issued when the demand for it was urgent, while securing its retirement as the demand fell off.

\section{The Aldrich Bill}

And now comes the Finance Committee of the United States Senate with a bill, in all its essential features, demanding absolute security for all issues to prevent distrust; with such a high tax6 per cent-as will bring such currency out only under stress, and will surely retire it as soon as pressure is over, thus preventing further inflation. These essentials seem to be ignored under the American Bankers' Association plan, because, under it, the currency, if issued, would be practically unsecured and would still further inflate our circulation.

The American Bankers' Association plan undoubtedly would arouse distrust in the minds of the masses, especially in troublous times, when it is of paramount importance to allay distrust. When panic is on, as the asset currency advocates claim a deposit is the same thing as asset currency, and local depositors are clamoring for cash, why will not eighty million holders of such currency demand coin on their notes, thus more than doubling our troubles under panic conditions? This is exactly what occurred in fiat money days. Taint our currency issues with a breath of suspicion, and our prosperity will be undermined as by an insidious disease. Even the first lien on assets, which would make the currency secure, but which would rob the depositors, is eliminated under this plan, thus increasing general distrust. Again, as the quick redemption theory will not work, which is now admitted by asset currency advocates, does any sane man believe that any bank in the United States 
with a right to issue asset currency, practically without collateral, paying only $2 \mathrm{I} / 2$ per cent per annum for the use of it, in the face of a 6 to Io per cent interest rate clear through 1907, would not have kept out the whole permissible amount for the profit in it, thus stretching the rubber currency to the limit. Under such conditions the reservoir would have been empty when the panic of I907 struck us. Would not the very object sought, relief under panic conditions, be defeated? The result would simply spell inflation, and inflation spells disaster. Such currency would expand, but not contract. The currency committee seems to have lost sight of the fundamental principle of Gresham's law. Britain, after a campaign as long and as bitter as ours over the Gresham Law, and the expulsion of her gold by the injection of too many bank notes into her circulation, unequivocally adopted the gold standard in 1816 . The integrity of that standard, as against the uncertainties of other national standards, has been maintained with a fidelity that commands the confidence of the whole world to such an extent that London has long been the world's clearing house. Will New York soon win that position if we inject an additional quantity of inferior currency into our circulation?

A wise man buildeth his house upon a rock, but the foolish man upon the sand. When the rain descends and the floods come and the winds blow, the wise man's house falleth not, but as to the foolish man's house, great is the fall thereof. Is not this a perfect simile to apply to the building up of the superstructure of our credit system upon a sound metallic currency for a foundation as against the shifting sands of a credit currency? The pages of history are strewn $w$ ith proofs that when the great instrument of exchange is deranged, all trade, all industry, is stricken as with a palsy. That instrument of exchange recognized by the world as the solid foundation that does not totter when the storm rages in its severest intensity, is the only foundation for a prosperous people to rest upon and to-day our coffers hold sixteen hundred million dollars of it. This is a billion dollar country, and we need these resources. This gold has come to us since 1873 in the natural course of trade, in response to the well-known principles of the Gresham law and monetary science, as expounded by Adam Smith, Ricardo, Jevons, Sumner and many other eminent economists, and as also clearly set forth in what Professor Sumner dubs 
the most important document in financial literature, "The Celebrated Bullion Report of 18 ro to the House of Commons." I have quoted these maxims before, but deep-seated error requires repetition of them again and again. Summed up these principles are:

(I) The cry of all ages is for "more money."

(2) Rich countries will have all the coin they need, providing no impolitic act of legislation interferes to force it out of circulation by the injection of inferior currencies.

(3) When the coin in any country exceeds the effectual demand, no vigilance of government can prevent its exportation.

(4) It is the province of government to settle the quality question of money, and the needs of commerce will settle the quantity.

In proof of the above maxims, history says, Chinese walls, jails, shot guns or hanging did not prevent exportation of coin, and in these modern days the object lesson of the exportation of more than thirty millions of gold in May and June, 1907, in the face of high interest rates and the plea of the asset currency advocates for "more money in the United States," is more potent than pages of logic. Let us fix the "quality" question and stop tinkering with the "quantity," as the needs of commerce will settle that.

With over I,700 million dollars of soft money in the United States to-day, would not the injection of 200 to 300 miltions of inferior asset or credit currency drive the same amount of gold out under the Gresham Law, thus undermining our metallic foundation for our great credit superstructure? Let us bend our energies to increase our metallic foundation and reduce our redundant soft money issues, if we would avoid trouble as far as human ingenuity can accomplish it. The only true remedy to compel conservatism is to penalize over-expansion of credit, instead of adding an unsecured asset currency stimulant. Throw a life line out to the over-confident, and he will be swimming beyond his depth continually.

\section{Asset Currency Fallacies}

The asset currency advocates are continually referring to the Canadian and Suffolk systems, also isolated cases in Indiana, Louisiana, Iowa and other states, as parallel to our conditions. Their arguments are as full of holes as a skimmer, and so-called parallels 
are as closely related as the Equator is to the North Pole. They are also continually quoting general European branch banking methods as systems for us to adopt. I stand with the masses of bankers of the country against a few great central banks owning all the banks of the country, because under that system, the branches practically pay no taxes where they are located; there is no real board of directors; few, if any, stockholders to whom dividends would be declared; in short the system simply skims the cream from the country towns to enrich the exchequers of the great centers, as is conclusively proved by the abnormally large profits made by the great central banks owning such branches.

\section{A National Reserve Bank}

As our independent banking system has worked wonders in the upbuilding of our hamlets and cities; as the quality of our money is unquestioned, and the quantity more than ample for normal conditions; as Europe has more nearly solved the "Elastic Problem" with fewer objectionable features than any plan yet suggested; why cannot we reject as entirely unnecessary the general branch banking feature, continue, if thought best, the United States sub-treasuries, with modifications as to cash holdings, and bring about elasticity through a national reserve bank. Such a bank would be owned by the banks of the country, and thus the profits would be theirs.

The capital stock might be $\$ 50,000,000$ and be taken in sums of not to exceed 5 per cent of the capital of each subscribing bank, to prevent monopoly. The Comptroller of the Currency, Secretary of the Treasury and United States Treasurer should be members of the Board of Directors. The National Reserve Bank, if such we may call it, might have authority to issue up to $\$ 250,000,000$ of national bank notes, as an experimental limit, under a tax of 6 per cent to drive it home as soon as pressure is over.

Again, under strained conditions, or when frightened depositors are demanding cash, and solvent merchants and manufacturers are calling for loans to pay bills and keep the wheels of commerce from being stilled, where is the banker that will not temporarily provide cash, if possible, at 6 per cent or even a higher rate, if necessary, instead of slaughtering sound securities in a hard market? Do not many bankers when capital demands exceed 
supply, get rediscounts now, and is much comment made unless rediscounts become excessive?

No interest should be paid upon deposits, nor should loans be made upon stocks, thus giving no aid to the stock gambling element. Such issues should be loaned only under conservative restrictions on quickly convertible securities. I believe if such a bank had been open in October, 1907, the panic with its train of evils might have been avoided, because the gamblers who were the cause of the outbreak could have been refused aid and thus have been weeded out as a future menace. The sound and solvent banks of New York could have been furnished with all the cash needed, because they have ample sound collateral. The country calls for balances in New York could have been promptly met with cash. Suspension of cash payments then would not have been necessary, and the result would have been that the whole country would not have been compelled to restrict cash payments nor to issue clearinghouse certificates.

On the other hand, if the American Bankers' Association's $21 / 2$ or 3 per cent currency plan had been authorized last winter, the full limit would have been out for the profit in it when the panic struck us. The National Reserve Bank plan will accomplish the object sought in an absolutely sound manner; it will checkmate locking up cash, as was done some months ago by a "bear" to the extent of $\$ 5,000,000$ in an attempt to bring on another Black Friday onslaught. The banks of the country will not hoard money in excess of needs, because they will know relief is at hand if needed.

It will not lead the bankers of the country generally to further expand their credit and thus feed the fires of speculation which have already gone beyond the limits of conservatism. It will not drive gold out of the country under Gresham's Law by the injection of any more inferior currencies, which must be avoided if our standard of values is to be maintained, and if New York City is ever to become the world's financial center. It will furnish cash at times when necessary to move the crops, or under panic conditions to loan to all solvent parties, that the wheels of commerce be not stilled and general paralysis result. The rate of interest will automatically drive home the extra issues as soon as confidence is restored; inflation will not result and the machinery will be ready for the next urgent call; IO, 20, 50, 100 per cent 
money will be unknown; the Secretary of the Treasury will heave a sigh of relief from pressing importunities; every bank in the country, whether national, state, private, savings or trust company, will, directly or indirectly, get relief if entitled to it. In the matter under discussion clearly the trend of all progressive countries is toward the concentration of the power to issue currency.

If this plan cannot be accomplished, then the plan brought out by the Senate Finance Committee, as a modification of Treasurer Treat's plan, will accomplish the relief sought, by the issue of extra currency amply secured to prevent distrust, with a tax sufficiently high to prevent inflation. These requirements are the main essentials.

A third plan, which would accomplish the relief sought, would be the issue of currency based on clearing-house certificates, such as have been lately issued. Such certificates should be deposited with the United States Treasurer as security for such issues. It is cash that fills demands and kills panic.

I prefer the central bank plan, because the machinery works smoothly and automatically, more so than under the second plan, and much more so than under the third. All three are sound, and infinitely better than asset currency, which will only produce distrust and inflation. Confidence upbuilds, distrust destroys. Statesmanship alone should reign. Whatever plan is provided, our standard of value should never be tarnished, because distrust breeds panic. On the contrary our currency should be above suspicion, that confidence, the great bulwark of all progress may be ours to the fullest possible extent. 